\title{
Article \\ Complete Genomic Characterization and Identification of Saccharomycopsis phalluae sp. nov., a Novel Pathogen Causes Yellow Rot Disease on Phallus rubrovolvatus
}

\author{
Xiaoxiao Yuan ${ }^{1,2,3}$, Keqin Peng ${ }^{1,2,3}$, Changtian Li ${ }^{2}$, Zhibo Zhao ${ }^{1}$, Xiangyu Zeng ${ }^{1}$, Fenghua Tian ${ }^{1,2,3, *}$ and $\mathrm{Yu} \mathrm{Li}^{2}$ \\ 1 Department of Plant Pathology, College of Agriculture, Guizhou University, Guiyang 550025, China; \\ xiaoxiaoyuanfungi@aliyun.com (X.Y.); pengkeqin@aliyun.com (K.P.); zbzhao@gzu.edu.cn (Z.Z.); \\ xyzeng3@gzu.edu.cn (X.Z.) \\ 2 Engineering Research Center of Chinese Ministry of Education for Edible and Medicinal Fungi, \\ Jilin Agricultural University, Changchun 130118, China; lct@jlau.edu.cn (C.L.); liyu@jlau.edu.cn (Y.L.) \\ 3 Institute of Edible Fungi, Guizhou University, Guiyang 550025, China \\ * Correspondence: fhtian@gzu.edu.cn
}

\section{check for}

updates

Citation: Yuan, X.; Peng, K.; Li, C.; Zhao, Z.; Zeng, X.; Tian, F.; Li, Y.

Complete Genomic Characterization and Identification of Saccharomycopsis phalluae sp. nov., a Novel Pathogen Causes Yellow Rot Disease on Phallus rubrovolvatus. J. Fungi 2021, 7, 707. https://doi.org/10.3390/jof7090707

Academic Editors: Samantha

C. Karunarathna and

Saowaluck Tibpromma

Received: 30 July 2021

Accepted: 27 August 2021

Published: 28 August 2021

Publisher's Note: MDPI stays neutral with regard to jurisdictional claims in published maps and institutional affiliations.

Copyright: (c) 2021 by the authors. Licensee MDPI, Basel, Switzerland. This article is an open access article distributed under the terms and conditions of the Creative Commons Attribution (CC BY) license (https:// creativecommons.org/licenses/by/ $4.0 /)$.

\begin{abstract}
Hongtuozhusun" (Phallus rubrovolvatus) is an important edible and medicinal mushroom endemic to Southwest China. However, yellow rot disease is a severe disease of $P$. rubrovolvatus that occurs extensively in Guizhou Province. It has caused major economic losses and hinders the development of the P. rubrovolvatus industry. In this study, 28 microorganism strains were isolated from diseased fruiting bodies of P. rubrovolvatus at various stages, two of which were confirmed to be pathogenic based on Koch's postulates. These two strains are introduced herein as Saccharomycopsis phalluae sp. nov. based on morphological, physiological, and molecular analysis. We reported a high-quality de novo sequencing and assembly of the S. phalluae genome using singlemolecule real-time sequencing technology. The whole genome was approximately $14.148 \mathrm{Mb}$ with a $\mathrm{G}+\mathrm{C}$ content of $43.55 \%$. Genome assembly generated 8 contigs with an N50 length of 1,822,654 bp. The genome comprised 5966 annotated protein-coding genes. This is the first report of mushroom disease caused by Saccharomycopsis species. We expect that the information on genome properties, particularly in pathogenicity-related genes, assist in developing effective control measures in order to prevent severe losses and make amendments in management strategies.
\end{abstract}

Keywords: edible and medicinal mushroom; de novo sequencing and assembly; Koch's postulates; Phallus rubrovolvatus; Saccharomycopsis sp. nov

\section{Introduction}

Phallus rubrovolvatus (M. Zang, D.G. Ji and X.X. Liu) Kreisel, Phallaceae, is a basidiomycete endemic to the temperate regions of Southwest China [1,2]. It is known as "Hongtuozhusun", "Flower of Fungi", or "Wild Foods" in Chinese (Figure 1A). Its fruiting body is white, delicate, refreshing, with high nutritional, medical and economic value [3,4]. Phallus rubrovolvatus cultivation in Guizhou Province, certified as a geographical indication product of China, is an industry that has a lot of investment and is highly efficient. Multiple planting modes, including simple greenhouse planting, intelligent layer planting, and undergrowth planting, were established in Guizhou Province. According to the Department of Agriculture and Rural Affairs of Guizhou Province, the scale of P. rubrovolvatus cultivation in 2020 was estimated to have exceeded 80 million sticks.

Earthing is an essential process during the cultivation of P. rubrovolvatus. It takes 4-10 months from earthing to harvest. During the process, the mushroom is vulnerable to many environmental microorganisms [5-7]. Diseases are common in P. rubrovolvatus but it is difficult to detect them in the early stages. Among them, yellow rot disease has caused many epidemics over the past 20 years, which has resulted in major yield 
reductions and economic losses (Figure 1B-D). However, the cause of the disease has remained ambiguous [8].
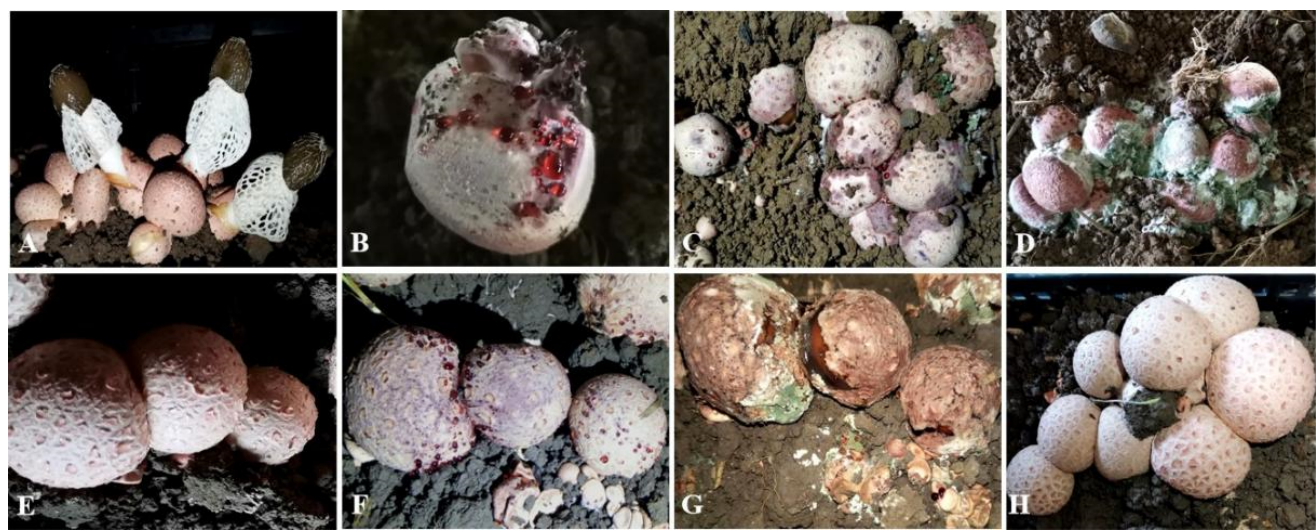

Figure 1. Field symptoms of yellow rot disease on Phallus rubrovolvatus and pathogenicity tests of isolate GUCC 202006 (2020060402-1). (A) Healthy fruiting bodies of P. rubrovolvatus. (B-D) Field symptoms of yellow rot disease on P. rubrovolvatus. (E-G) Pathogenicity tests, after spraying with $0.5 \mathrm{~mL}$ spore suspension $\left(1 \times 10^{6}\right.$ conidia $\left.\mathrm{mL}^{-1}\right)$. (E) Day 0 after inoculation; $(\mathbf{F})$ Reddish water droplets on the surface of the fruiting body, 4 days after inoculation; (G) Whole fruiting body rotten, 7 days after inoculation. (H) Control, no disease, 7 days after inoculation with distilled water.

Saccharomycopsis was introduced by Schiønning [9] as a member of the family Saccharomycopsidaceae [10]. Saccharomycopsis species are characterized by multi-polar budding and septate hyphae. Significant variations in the ascospore shape can lead to the false assignment of these species to other genera such as Endomyces and Arthroascus [11]. There are 19 species of Saccharomycopsis in Index Fungorum as (http:/ / www.indexfungorum. org/Names/Names.asp, accessed on 26 August 2021). Saccharomycopsis fibuligera and Saccharomycopsis cerevisiae were developed as sourdough bread starters [12]. Additionally, Saccharomycopsis fibuligera was reported as a specific biocontrol agent of ochratoxic molds (Aspergillus ochraceus and Penicillium nordicum) [13]. However, Saccharomycopsis has not been reported as a plant or mushroom pathogen.

The present study reports for the first time on the association of the genus Saccharomycopsis with yellow rot symptoms on P. rubrovolvatus in China. The objective of the study was to identify the causal agent of yellow rot disease on P. rubrovolvatus in Guizhou Province, China. Herein, they are introduced as a novel species in the genus Saccharomycopsis (family Saccharomycopsidaceae) based on morphological and physiological evaluation and phylogenetic analyses. The genome of the causal agent was sequenced and annotated. We expect our findings to provide a reference for effective prevention and control of yellow rot disease on P. rubrovolvatus.

\section{Materials and Methods}

\subsection{Pathogen Isolation and Maintenance}

Diseased fruiting bodies of $P$. rubrovolvatus at three different degrees of disease (two samples/degree) were collected from a mushroom cultivation base, Nayong county $\left(105^{\circ} 20^{\prime} 31^{\prime \prime}\right.$ N, $26^{\circ} 53^{\prime} 41^{\prime \prime}$ E), Guizhou Province, China, in March 2020.

Each basidiocarp was first externally washed with running tap water. Next, the site of the disease was cut off with a cleansing knife and surface sterilized with $95 \%$ ethanol for $1 \mathrm{~min}$, rinsed with sterilized distilled water twice, immersed in $75 \%$ ethanol for $30 \mathrm{~s}$, and then rinsed in distilled water three times. The diseased tissue was crushed, immersed in sterilized water, and then subjected to gradient dilution. Low-titer spore suspensions were spread on a potato dextrose agar plate. For each sample, the single colonies formed by germination were re-isolated and purified after 4 days of incubation at $25^{\circ} \mathrm{C}$, in darkness. Experiments of each sample were in triplicate. The holotype specimen was deposited in the 
Herbarium of the Department of Plant Pathology, Agricultural College, Guizhou University (HGUP). All pure cultures were deposited in the Culture Collection of the Department of Plant Pathology, Agriculture College, Guizhou University, China (GUCC) and in the Mycological Institute of Jilin Agricultural University (HMJAU). All isolates are maintained in $25 \%(v / v)$ glycerol at $-80^{\circ} \mathrm{C}$ for long-term storage.

\subsection{Pathogenicity Tests}

All isolates were tested for pathogenicity using 3 to $4 \mathrm{~cm}$ diameter fruiting body stages of $P$. rubrovolvatus following a modified protocol of Tian et al. [14]; 20 fruiting bodies were sprayed with $0.5 \mathrm{~mL}$ spore/cell suspension $\left(1 \times 10^{6}\right.$ spore/cell mL $\left.{ }^{-1}\right)$, while another 20 replicates were sprayed with sterilized distilled water as the controls. These fruiting bodies were maintained under the same conditions $\left(22-24{ }^{\circ} \mathrm{C}, 90-95 \%\right.$ relative humidity) and symptom development was assessed. The pathogenicity test was assessed over 7 days. The strains were re-isolated from the infected fruiting bodies and identified based on morphological and phylogenetic analyses. All experiments were conducted in triplicate.

\subsection{Morphological, Physiological, and Molecular Characterization}

To observe the morphology of the colonies and cells, the pathogens were cultured (1) on a yeast-peptone-glucose (YPG) medium that consisted of $0.5 \%$ yeast extract, $1.0 \%$ peptone, $2.0 \%$ glucose, and $1.6 \%$ agar, which were all obtained from Sigma-Aldrich (St. Louis, MO, USA), at $25^{\circ} \mathrm{C}$ and (2) in YPG broth at $28^{\circ} \mathrm{C}$ in darkness [15-17].

Additionally, the physiological and biochemical characteristics of the isolates were determined according to the standard methods described by Kurtzman et al. and Barnett et al. $[16,18]$. Furthermore, to assess the molecular characteristics of the isolates, total genomic DNA was extracted from the colony of the two pathogenic isolates using a CWBIOTECH Plant Genomic DNA Kit (Beijing, China) following the manufacturer's protocol. The internal transcribed spacer (ITS) region of the rDNA gene cluster and the D1/D2 domains of the large ribosomal subunit (LSU, 26S) were amplified by PCR with primers ITS4/ITS5 [19] and NL1/NL4 [20].

PCR was conducted in a T100 Thermal Cycler (Bio-Rad Laboratories Inc., Hercules, CA, USA). The total reaction volume of the PCR reaction was $25 \mu \mathrm{L}$, consisting of $1.6 \mu \mathrm{L}$

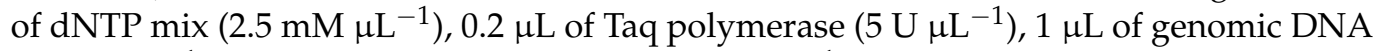
(50 ng $\left.\mu \mathrm{L}^{-1}\right), 2 \mu \mathrm{L}$ of polymerase buffers $\left(10 \times \mu \mathrm{L}^{-1}\right.$, Takara, Japan), and $1 \mu \mathrm{L}$ of each primer $\left(25 \mathrm{mM} \mathrm{LL}^{-1}\right)$. Amplification of the ITS region was performed as follows: initial denaturation for $5 \mathrm{~min}$ at $94^{\circ} \mathrm{C}, 30$ cycles of $30 \mathrm{~s}$ at $94^{\circ} \mathrm{C}, 30 \mathrm{~s}$ at $50^{\circ} \mathrm{C}$, and $30 \mathrm{~s}$ at $72{ }^{\circ} \mathrm{C}$, with a final extension for $10 \mathrm{~min}$ at $72{ }^{\circ} \mathrm{C}$. Amplification of the fragment of the D1/D2 domains was performed as follows: initial denaturation for $3 \mathrm{~min}$ at $94{ }^{\circ} \mathrm{C}, 36$ cycles of $30 \mathrm{~s}$ at $94{ }^{\circ} \mathrm{C}, 30 \mathrm{~s}$ at $53{ }^{\circ} \mathrm{C}$, and $60 \mathrm{~s}$ at $72{ }^{\circ} \mathrm{C}$, with a final extension for $5 \mathrm{~min}$ at $72{ }^{\circ} \mathrm{C}$. Electrophoresis was performed on $0.8 \%$ agarose gels stained with Gel Green. PCR products were sequenced by using the same PCR primers used in amplification reactions by Sangon Biotech (Shanghai, China) Co., Ltd.

Kurtzman and Roberts determined the sequence (about 500-600 bp) of the large subunit rRNA gene (26S rDNA) of almost all known yeast taxon. It was found that most species could be distinguished by this marker, and the base difference between different strains within the species was not more than 1\% [21-23]. The obtained sequences were visualized using BioEdit v7.2.5 [24] and compared to the non-redundant nucleotide collection (nr/nt) sequences present in the National Center for Biotechnology Information (NCBI) GenBank database using nucleotide Basic Local Alignment Search Tool (BLASTn, https:/ / blast.ncbi.nlm.nih.gov / Blast.cgi, accessed on 10 March 2021). Phylogenetic trees were constructed using maximum likelihood (ML), maximum parsimony (MP), and Bayesian inference (BI) via the CIPRES web portal [25]. The phylogenetic analyses were conducted using 40 strains, including our two strains, 18 species of Saccharomycopsis, 2 unclassified Saccharomycopsis spp., and phylogenetically related species of Candida, Alloascoidea, Ascoidea, and Wickerhamomyces $[17,23]$. 


\subsection{Whole-Genome Sequencing and Assembly}

Total DNA of the causal agent strain GUCC 202006 (2020060402-1) was extracted using the NuClear Plant Genomic DNA kit (Tiangen Biotech, Beijing, China). We constructed 20-kb libraries, and the genome was sequenced with a PacBio Sequel long-read sequencing platform. RS_HGAP_Assembly.4 protocol was used for assembly and Quiver for genome polishing in SMRT Analysis v3.2.0 [26,27]. High-throughput sequencing on an HiSeq PE150 system (Illumina, San Diego, CA, USA) was carried out to correct the base errors caused by the assembly of long reads from the PacBio SEQUEL using Pilon v1.22 [28]. We assessed integrity at both ends of scaffolds by telomeric repeats (TTAGGG/CCCTAA) [29].

\subsection{Gene Prediction and Genome Annotation}

Augustus v3.2.2 was used for denovo prediction of the protein-coding genes as Stanke et al. [30] (-genemodel=complete - gff $3=$ on - species=haishen haishen.yanzheng.fasta $>$ augustus.gff). Repeat Masker v4.0.5 was used to identify and mask the repeat sequences [31]. Tandem repeat sequences were identified by the Tandem Repeats Finder v4.07b [32]. The predicted protein-coding genes were functionally annotated by BLASTP (blastp -db \$swiss query \$faa -out \$prefix.swiss.bsp -outfmt 0 -evalue 1e-5 -num_threads 40 -num_descriptions 5 -num_alignments 5 \&) query against eleven databases, such as the NCBI Non-redundant (nr) [33], Gene Ontology (GO) [34], Eukaryotic Orthologous Groups (KOG) [35], Pfam [36], Kyoto Encyclopedia of Genes and Genomes (KEGG) [37,38], the SwissProt database [39], Transporter Classification Database (TCDB) [40], Pathogen-Host Interactions Database (PHI-base) [41], Carbohydrate-active enzymes (CAZymes) [42], and Cytochrome P450 monooxygenase (P450) [43].

\subsection{Orthological, Phylogenetic Tree Construction}

OrthoMCL software (v.2.0.9) [44] and all-versus-all BLASTP [45] were used with the parameters (E-value $\leq 1 \times 10^{-15}$, coverage $\geq 50 \%$ ) to identify the orthologous gene families based on the coding sequence (CDSs) of S. phalluae, S. fermentans, S. schoenii, S. fodiens, S. sp. UWO(PS) 91-127.1, S. fibuligera, S. malanga, S. capsularis and 20 other selected genomes were obtained from the NCBI database (Table S1). The shared single-copy genes were screened and aligned using Clustal omega [46]. The proTest was used to generate an optimal base substitution model with maximum likelihood (ML) algorithm in RA $\times$ ML [47], with Scheffersomyces stipitis CBS 6054 as the outgroup.

\section{Results}

\subsection{Pathogen Isolation, Pathogenicity Tests and Identification}

Yellow rot disease is a severe and extensive disease of $P$. rubrovolvatus, infecting up to $60 \%$ of the fruiting bodies (Figure 1B-D). At the early stage, the disease is characterized by reddish water droplets on the surface of the fruiting bodies. Initially, a lot of droplets appear on the surface of the fruiting bodies, and the whole fruiting body then decays. Additionally, many other microorganisms grow with the development of the disease, such as bacteria, fungi, myxomycetes, nematodes, insects, and mites. The disease can spread rapidly to adjacent fruiting bodies resulting in abnormal $P$. rubrovolvatus growth and harvest failure.

Among the 28 isolates that were obtained from the diseased fruiting bodies, only strains GUCC 202006 (2020060402-1) and GUCC 202007 (2020060503-2) were pathogenic (Figure S1). The pathogenicity results showed that yellow rot disease symptoms were visible 3 days after inoculation with the spore suspension, with clear symptoms developing at 4 days post-inoculation. The whole fruiting body decayed at 7 days after inoculation. These symptoms from artificial inoculation were similar to those observed in the field (Figure 1E-G). The control were without disease on the 7 day (Figure 1H). To fulfill Koch's postulates, the pathogens were consistently re-isolated from the infected fruiting bodies of $P$. rubrovolvatus and confirmed to be consistent with the inoculated strain based on morphological and molecular characteristics. 
The physiological and biochemical characteristics were identical between the two strains. The key characteristics of the proposed novel species and related type strains in the genus Saccharomycopsis are compared in Table 1.

Table 1. Physiological characteristics of strain $2020060402-1^{\mathrm{T}}$ and related type strains of Saccharomycopsis species.

\begin{tabular}{cccccc}
\hline Characteristic & $\mathbf{1}$ & $\mathbf{2}^{\mathbf{a}}$ & $\mathbf{3}^{\mathbf{b}}$ & $\mathbf{4}^{\mathbf{c}}$ & $\mathbf{5}^{\mathbf{d}}$ \\
\hline D-glucose fermentation & - & $\mathrm{W} /-$ & $\mathrm{W} / \mathrm{V}$ & - & - \\
Maximum growth temperature & $35^{\circ} \mathrm{C}$ & $\mathrm{ND}$ & $33^{\circ} \mathrm{C}$ & $35^{\circ} \mathrm{C}$ & $28^{\circ} \mathrm{C}$ \\
Growth in $5 \% \mathrm{NaCl}$ & - & $\mathrm{ND}$ & - & $\mathrm{ND}$ & + \\
Growth in $10 \% \mathrm{NaCl}$ & - & - & $\mathrm{ND}$ & + & - \\
Potassium nitrate & + & - & - & + \\
\hline
\end{tabular}

Taxa: (1) 2020060402-1 ${ }^{\mathrm{T}}$; (2) S. crataegensis strain NRRL Y-5902 ${ }^{\mathrm{T}}$; (3) S. fodiens strain CBS 8332 ${ }^{\mathrm{T}}$; (4) S. guyanensis strain CBS $12914^{\mathrm{T}}$; (5) S. oxydans strain IBRC-M 30374 ${ }^{\mathrm{T}}$. Codes: +, positive; w, weakly positive; -, negative; V, variable; ND, not determined. Data are from this study, except those that are labeled as follows: a data from Kurtzman et al., (2011); ${ }^{b}$ data from Lachance et al. (2012); ${ }^{c}$ data from Jacques et al. (2014); ${ }^{d}$ data from Hajihosseinali et al. (2020).

The sequences of the two isolates, GUCC 202006 and GUCC 202007, were identical. The ITS and LSU sequence data were deposited in GenBank (GUCC 202006 (20200604021), type strain: ITS MW412929 and LSU MW405828; GUCC 202007 (2020060503-2): ITS MW412927 and LSU MW405829).

The phylogenetic analyses based on LSU sequences showed that our two strains clustered together with high statistical support (ML/MP/BI: 100\%/99\%/1.00). The novel species is the sister of Saccharomycopsis oxydans IBRC M-30374 ${ }^{\mathrm{T}}$, based on high statistical support (92\%/100\%/1.00) (Figure 2). Based on the morphology, physiology and phylogeny results, the two pathogenic strains are introduced as Saccharomycopsis phalluae sp. nov.

Saccharomycopsis phalluae FH Tian, XX Yuan \& KQ Peng, sp. nov.

Diagnosis: The cells infected fruiting body of Phallus rubrovolvatus, causing yellow rot disease. Characterized with multi-polar budding and septate hyphae. Cells were ellipsoidal to elongate. The margins on cultures were regular. Additionally, the colony could turn reddish-brown in the center after 5 days on YPG agar.

Holotype: Voucher number-HGUP 20064 (deposited in the Herbarium of the Department of Plant Pathology, Agricultural College, Guizhou University, China), collected by F.H. Tian, X.X. Yuan and K.Q. Peng on 10 March 2020 at Nayong county, Guizhou Province, diseased fruiting body from a mushroom cultivation base (Figure 1B,C).

Isotype: GUCC 202006, GUCC 202007, deposited in GUCC, China. ITS region sequence $=$ GenBank accession no. MW412929, MW412927, respectively; LSU sequence $=$ GenBank accession no. MW405828, MW405829, respectively.

Type locality: Nayong county, Guizhou Province, China $\left(105^{\circ} 20^{\prime} 31^{\prime \prime} \mathrm{N}, 26^{\circ} 53^{\prime} 41^{\prime \prime} \mathrm{E}\right)$.

Etymology: Named after the host genus from which it was collected, Phallus.

Chinese name: Zhu Sun Sheng Kou Nang Fu Mo Jiao Mu 竹蒜扣囊复膜酵母

Distribution: China, Guizhou Province, Bijie City, Nayong county.

Habitat: Cells on the diseased fruiting body of Phallus rubrovolvatus.

Indexfungorum: IF558187

Morphological description of the pathogen after growth on YPG agar for 3 days at $25{ }^{\circ} \mathrm{C}$ : streak culture is white, smooth, glossy, butyrous, convex. Colony margins are regular (Figure 3A,B). The colony turned reddish-brown in the center after 5 days (Figure 3B,C). The cells are ellipsoid to elongate, and measure 5.6-10.4 × 2.4-4.8 $\mu \mathrm{m}$ (av. $7.6 \mu \mathrm{m} \times 3.7 \mu \mathrm{m}$, $n=25$ ), and occur singly or occasionally in pairs. After 15 days, pseudohyphae can be observed at the margin of the colony, and they have a consistent form after subculturing (Figure 3C,D,H-L). 


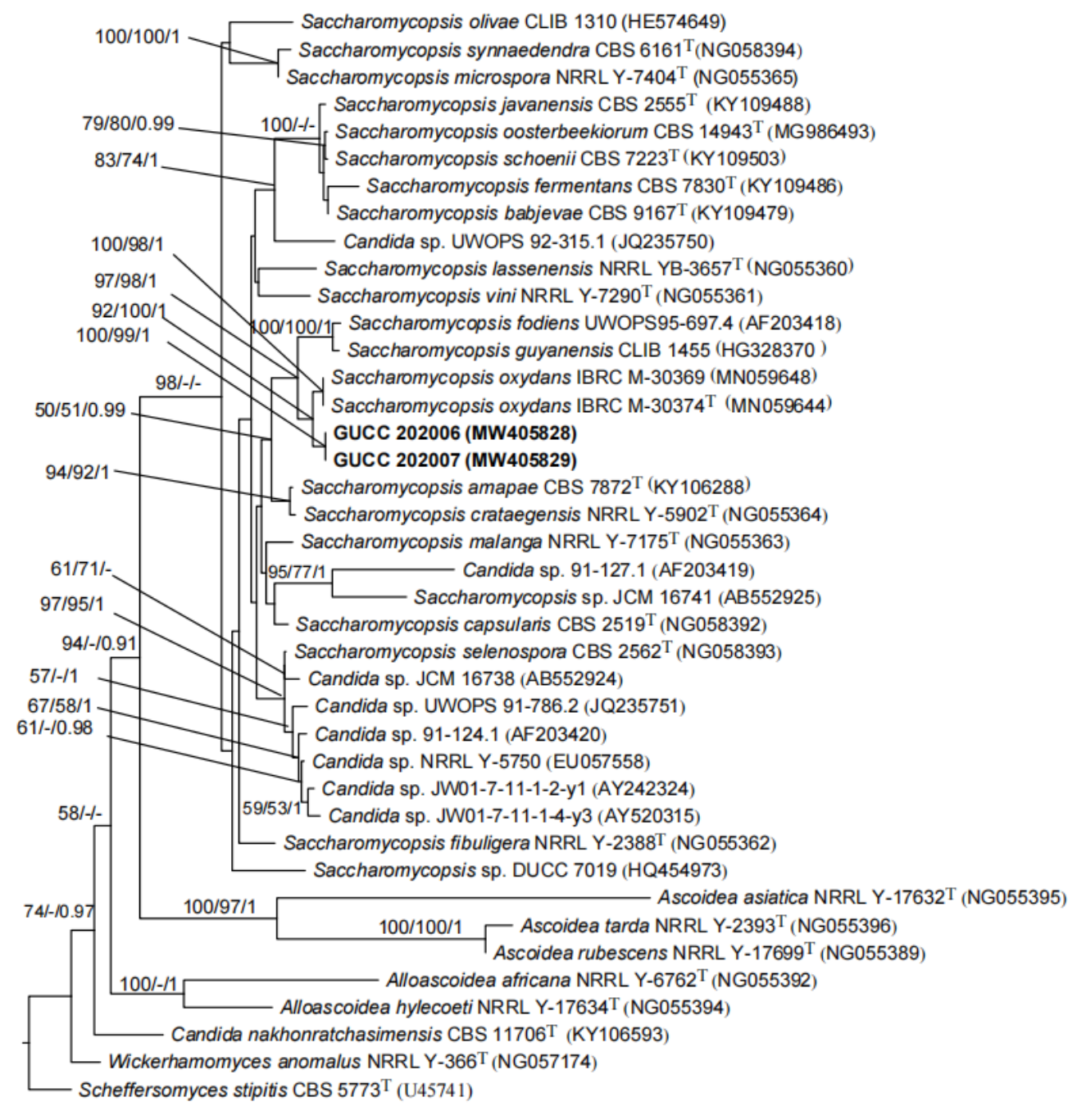

0.07

Figure 2. Phylogenetic tree based on LSU gene sequences for our two strains and selected reference isolates retrieved from GenBank. Maximum parsimony (MP) values, maximum likelihood (ML) values $>50 \%$ and Bayesian inference $(\mathrm{BI})$ values $>0.90$ are shown next to topological nodes and separated by "/". Bootstrap values $<50 \%$ and BI values $<0.90$ are labeled with "-". Ex-type strains are marked with "T". The tree was rooted to Scheffersomyces stipitis CBS $5773^{\mathrm{T}}$. The two strains in bold were Saccharomycopsis phalluae sp. nov.

Morphological description of the pathogen after growth in YPG broth for 2 days at $28{ }^{\circ} \mathrm{C}$ in darkness: cells are ellipsoid to elongate and occur singly or in pairs (Figure $3 \mathrm{E}-\mathrm{G}$ ). No sexual structures observed. Regarding fermentation ability: negative for D-glucose, maltose, sucrose, lactose, and raffinose. Potassium nitrate, sodium nitrite, glucosamine, cadaverine, and imidazole were assimilated. Growth is weakly positive at $10{ }^{\circ} \mathrm{C}$ but positive at $20,24,26,28,30$, and $32^{\circ} \mathrm{C}$ after 3 days. No growth is detected at 35 or $37^{\circ} \mathrm{C}$. Growth is positive in the presence of $0.1 \%$ cycloheximide. No growth occurs on $5 \%$ or $10 \%$ $\mathrm{NaCl}$. Starch-like compounds are not produced.

Molecular characteristics (type strain, 2020060402-1 ${ }^{\mathrm{T}}$ ): nucleotide sequences of the ITS region (accession no. MW412929) and the D1/D2 domains (accession no. MW405828) of the LSU (26S) were deposited in NCBI GenBank. 


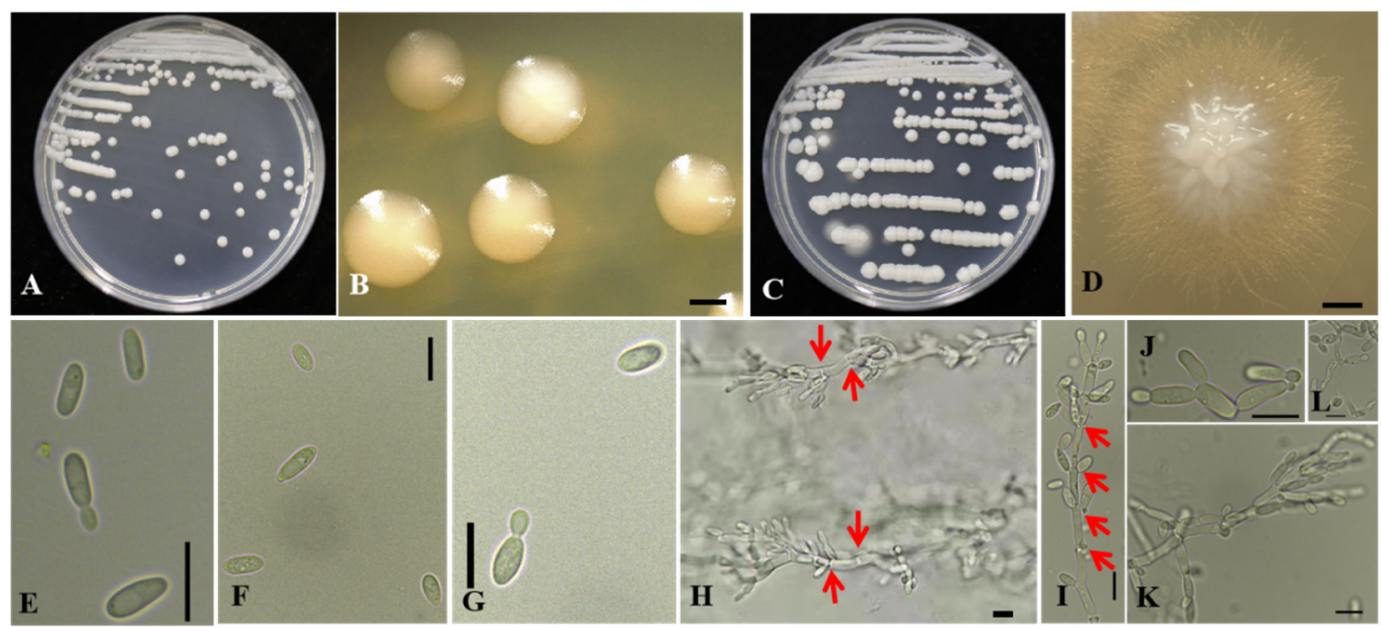

Figure 3. Morphological characterization of Saccharomycopsis phalluae sp. nov. GUCC 202006 on YPG agar. (A) White colony on YPG agar at $25{ }^{\circ} \mathrm{C}$ after 3 days of incubation. (B) Regular colony margins, bar $=500 \mu \mathrm{m}$. (C) Pseudohyphae at the edge of the colony. (D) Pseudohyphae exhibiting a consistent form after subculturing, bar $=500 \mu \mathrm{m}$. (E) Budding cells in YPG broth, bar $=10 \mu \mathrm{m}$. $(\mathbf{F}, \mathrm{G})$ Budding cells on YPG broth, bar $=10 \mu \mathrm{m}$. $(\mathbf{H}-\mathbf{L})$ Pseudohyphae with septate cells (red arrows: cell membrane) on YPG agar, bar $=10 \mu \mathrm{m}$.

Type: China, Guizhou Province, isolated from diseased Phallus rubrovolvatus (edible and medicinal fungi, Basidiomycete), Fenghua Tian [GUCC 202006] (holotype GUCC 202006; ex-type culture HMJAU 201004-20).

Note: Phylogenetic analysis based on LSU sequence data showed that our strains were the sister species of S. oxydans S. Nasr and A. Yurkov, but with 1.8\% (9/505 nucleotides) variation. Morphologically, our strains differ from S. oxydans by having ellipsoidal to elongate cells instead of ovoid to short cylindroid cells. The margins on cultures of S. oxydans are irregular while margins on cultures of S. phalluae are regular. Additionally, the colony of our strains turned reddish-brown in the center after 5 days on YPG agar, while $S$. oxydans lacks this characteristic. In the phylogenetic analyses, 18 species of Saccharomycopsis were included, as the LSU sequence data of S. phaeospora was not available. However, S. phaeospora has cells with truncate base rather than broad base [48].

\subsection{Features of the S. phalluae Genome}

In total, 96,001 reads number $(600 \times$ Depth) were obtained, from which a $14.148 \mathrm{Mb}$ assembly was estimated. The genome consisted of 8 contigs with N50 of 1,822,654 bp, N90 of 1,540,684 bp, and $43.55 \% \mathrm{G}+\mathrm{C}$ content (Table 2), among which contig1, 3, 4 and 5 include complete $5^{\prime}$ and $3^{\prime}$ terminal telomere structure, and contig 2, 6, 7 and 8 only have $3^{\prime}$ terminal telomere structure.

A BLAST search of repeat sequences yielded $12,316,384$ bp covering $87.05 \%$ of the S. phalluae genome; meanwhile, short interspersed nuclear elements (SINE) accounted for $0.06 \%$ of the genome. Approximately $3.65 \%$ of the genome was long terminal repeats (LTRs), $0.33 \%$ was DNA transposons, and $3.91 \%$ was long interspersed nuclear elements (LINEs), while minisatellite and microsatellite DNA accounted for $0.07 \%$ of the genome.

\subsection{Functional Annotation of S. phalluae}

There were 5966 gene models predicted in the different databases, accounting for $46.56 \%$ of the whole genome with an average sequence length of $1,480 \mathrm{bp}$ (Tables S2 and S3). We predicted 232 tRNAs (18,914 bp), 2 rRNAs (240 bp), 12 snRNAs (1015 bp), 2 miRNAs (204 bp), and 8 others (1706 bp). 
Table 2. General features of the S. phalluae genome.

\begin{tabular}{cc}
\hline Scaffold Characteristic & \\
\hline Total counts of contigs sequences & 8 \\
Total length of contigs sequences (bp) & $14,148,124$ \\
Contigs N50 (bp) & $1,822,654$ \\
Contigs N90 (bp) & $1,540,684$ \\
Largest scaffold length (bp) & $2,335,166$ \\
Genome coverage & $600 \times$ \\
GC content (\%) & 43.55 \\
\hline Genome Characteristic & \\
\hline Gene number & 5966 \\
Average gene length (bp) & 1480 \\
Exon number per Gene & 0.4 \\
Exon average length (bp) & 1.14 \\
Genome GC percent (\%) & 1298 \\
Exon GC percent (\%) & 43.55 \\
\hline
\end{tabular}

Annotation was performed with the NCBI nr, KEGG, GO, KOG, TCDB, PHI-base, CAZy, and P450 databases (Table 3 and Table S3). There were 4,735 Non-redundant proteins found in S. phalluae. They matched closest with Ascoidea rubescens (1252), Wickerhamomyces anomalus (433), Pachysolen tannophilus (311), Wickerhamomyces ciferrii (286), Cyberlindnera fabianii (251), Babjeviella inositovora (180), and Kuraishia capsulata (160), which accounted for $60.68 \%$ of total $\mathrm{nr}$ predicted genes (Figure 4 ).

Table 3. Summary of S. phalluae gene annotations.

\begin{tabular}{cc}
\hline Database Used for Gene/Protein Annotation & Number of Genes \\
\hline nr & 4735 \\
GO & 3921 \\
KEGG & 1968 \\
KOG & 4015 \\
PHI & 1461 \\
CAZy & 1779 \\
P450 & 220 \\
\hline
\end{tabular}

nr, National Center for Biotechnology Information Non-redundant Protein Database; GO, Gene Ontology; KEGG Kyoto Encyclopedia of Genes and Genomes; KOG, Eukaryotic Orthologous Groups; TCBD, Transporter Classification Database; PHI, Pathogen-Host Interactions Database; CAZy, Carbohydrate-active Enzymes Database; P450, cytochrome P450 monooxygenase.
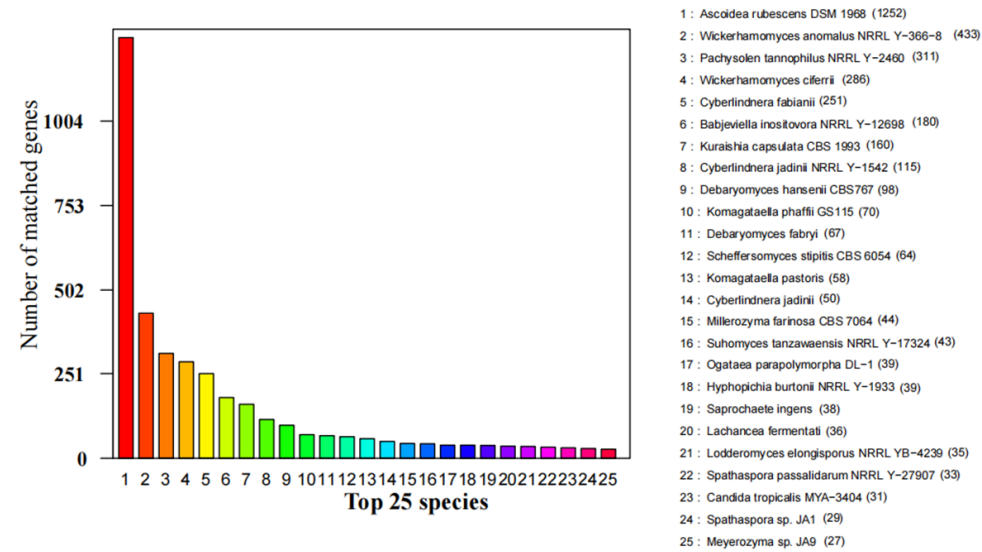

Figure 4. Predicted proteins from S. phalluae genome to the NCBI non-redundant proteins database among different fungal species. 
There were 4015 proteins assigned to NCBI KOG categories (Figure 5). The "General function prediction only" category had the most enriched genes (572), followed by "Posttranslational modification, protein turnover, chaperones" (428), "Translation, ribosomal structure and biogenesis" (290), "Intracellular trafficking, secretion, and vesicular transport" (276), and "Signal transduction mechanisms" (259). The representation of genes related to protein and energy metabolism may reflect the capacity of $S$. phalluae to absorb and transform nutrients from a variety of substrates.
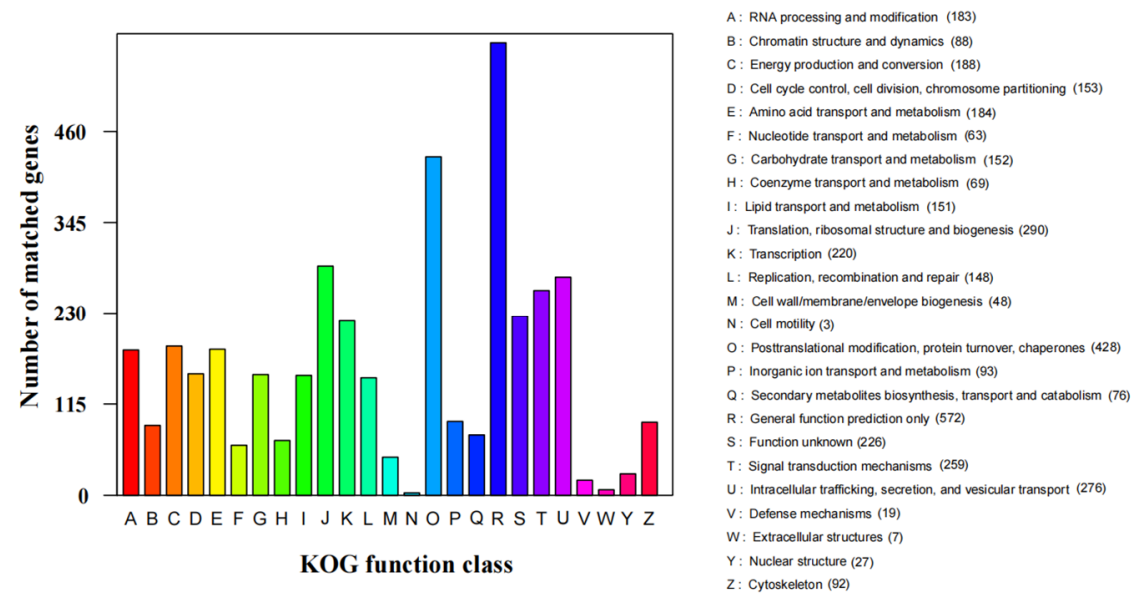

Figure 5. KOG functional classification of $S$. phalluae proteins.

Predicted genes were mapped to the KEGG database and assigned functional classifications to 1968 gene models (32.99\% of the total gene models, 5966) (Figure 6). Some categories related to protein families and metabolism were highly enriched including "Genetic information processing" (640), "Metabolism" (285), "Signaling and cellular processes" (165), "Carbohydrate metabolism" (119), "Amino acid metabolism" (96), "Metabolism of cofactors and vitamins" (79), "Lipid metabolism" (65) and so on. There also found 155 Unclassified: metabolism.

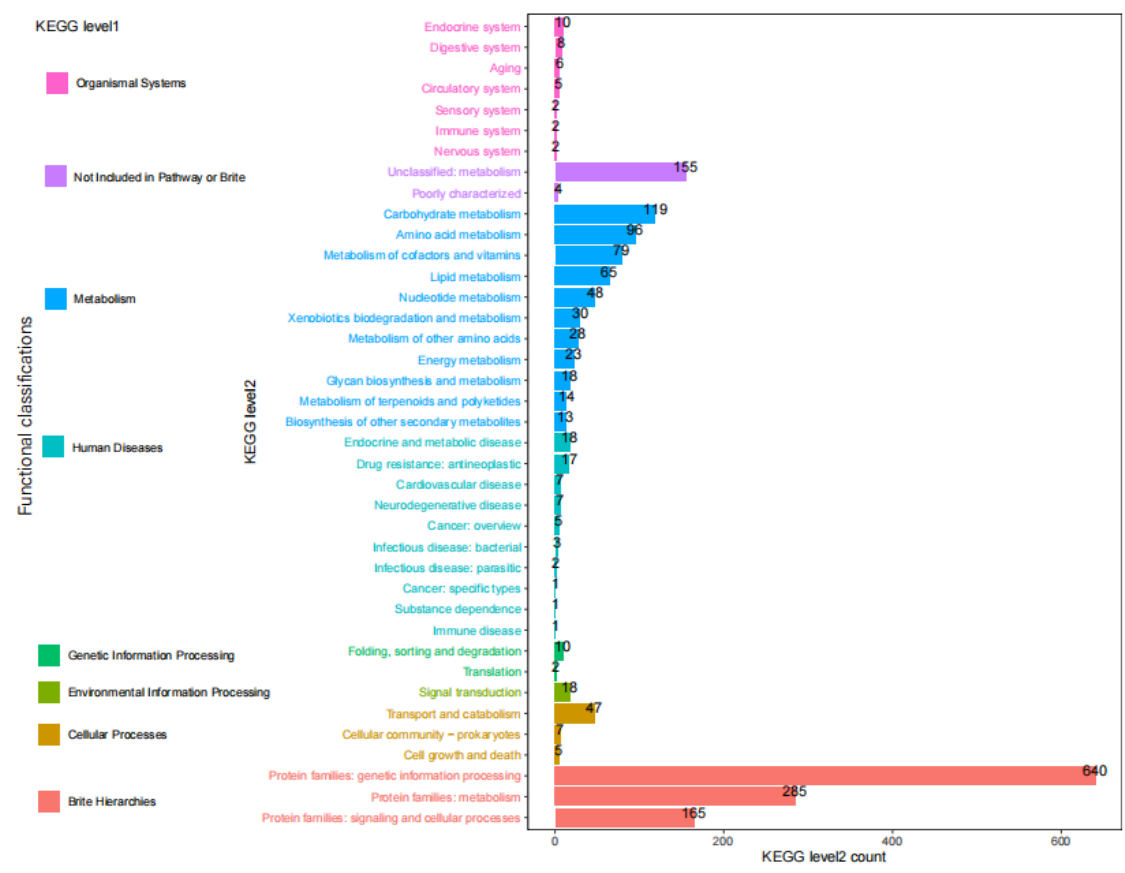

Figure 6. KEGG pathway annotation of S. phalluae genes. 
The TCDB database was to perform protein domain analysis and assigned 290 putative transport proteins to 7 functional classes including "Accessory factors involved in transport", "Channels/pores", "Electrochemical potential-driven transporters", "Group translocators", "Incompletely characterized transport systems", "Primary active transporters", and "Transmembrane electron carriers" (Figure 7). The top two enriched categories were "P-P bond hydrolysis-driven transporters" (290) and "Porters (uniporters, symporters, antiporters)" (271).
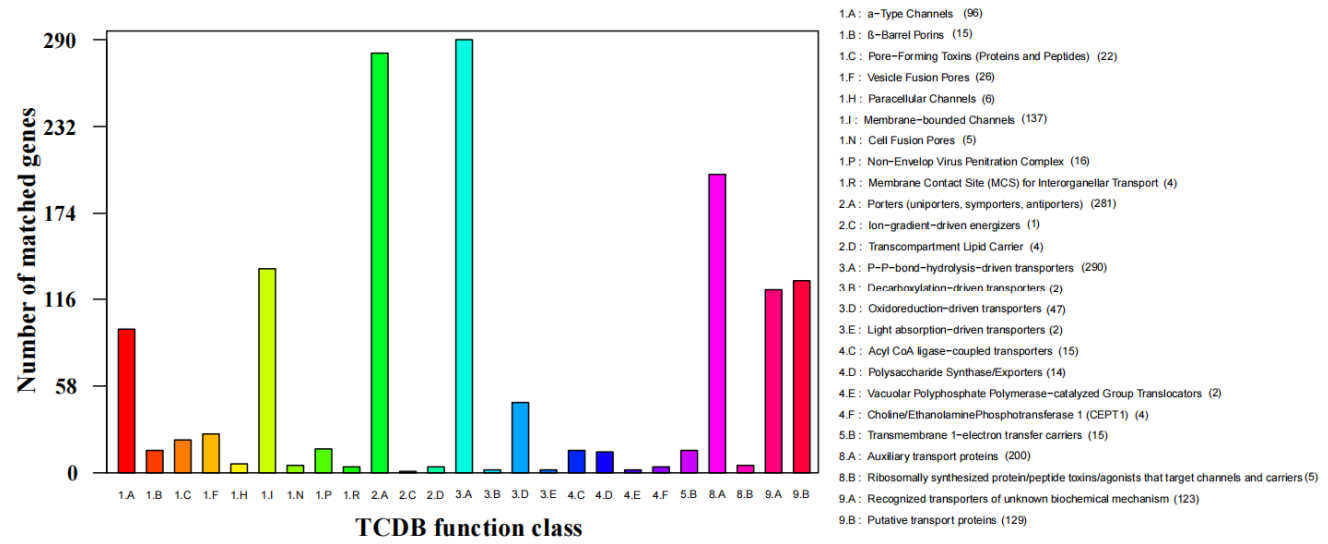

Figure 7. TCDB functional annotation of $S$. phalluae genes.

In terms of GO functional classes, 3921 proteins were predicted accounted for $65.72 \%$ of the total predicted genes in S. phalluae. The top eight most highly enriched proteins were predicted in terms of GO functional classes, that accounted GO terms were "Binding", "Catalytic activity", "Metabolic process", "Cellular process", "Single-organism process", "Cell", "Call part", and "Biological regulation" (Figure 8).

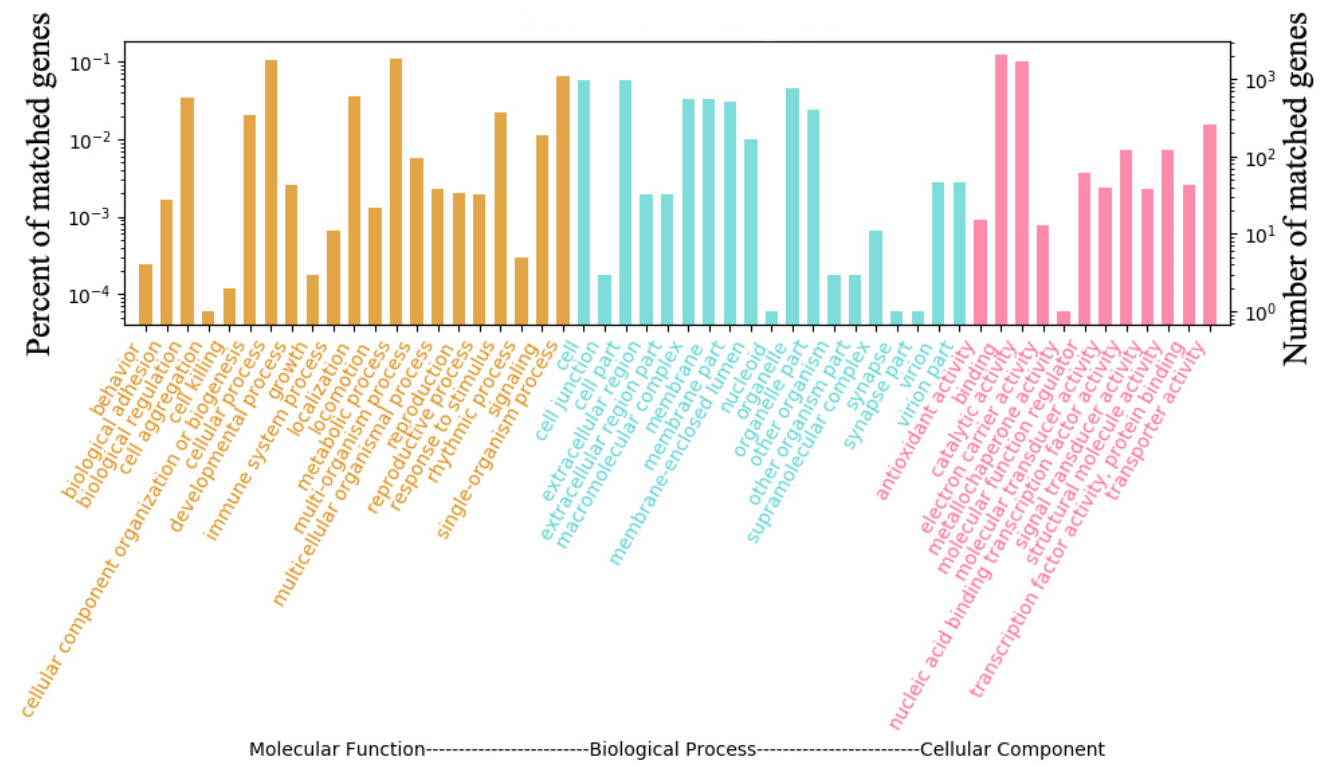

Figure 8. GO functional annotation of S. phalluae genes.

Amino acid sequences were mapped with PHI-base and identified 1779 candidate pathogenicity-related proteins (Figure 9). The "Reduced virulence" category had the most enriched proteins (799), followed by "Unaffected pathogenicity" (402), "Effector (plant avirulence determinant)" (210), together these represented $79.31 \%$ of all proteins predicted with PHI-base. 


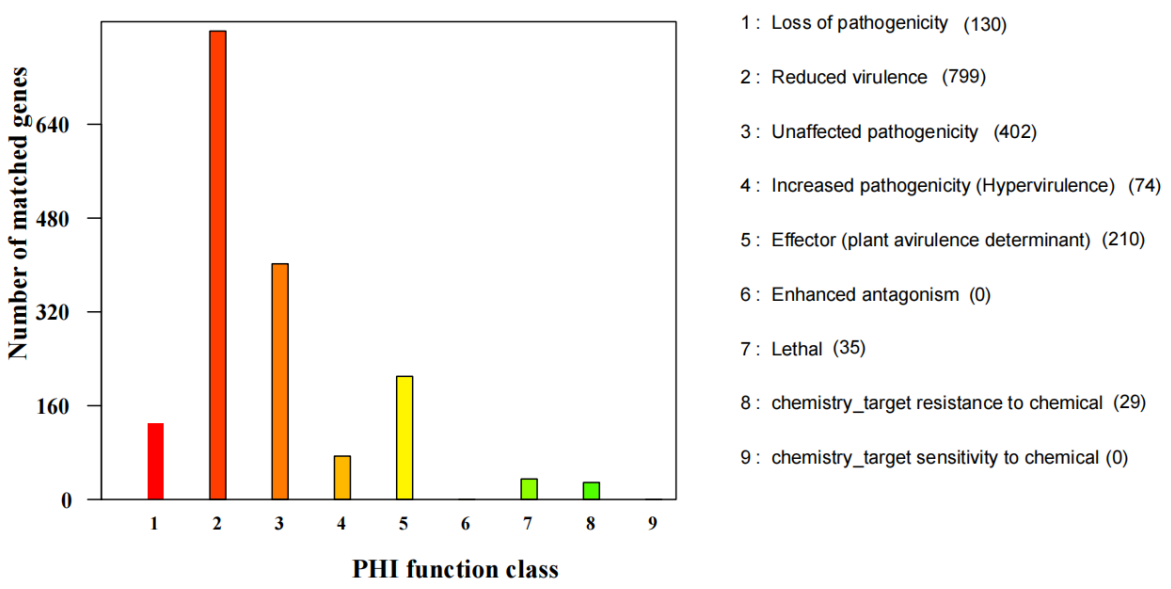

Figure 9. PHI functional annotation of S. phalluae genes.

Cytochrome P450 (CYP) is a superfamily of hemoproteins that use heme as a cofactor. CYPs have various substrates in different enzymatic reactions and are present in all kingdoms. Eighty-three putative CYPs genes were identified in S. phalluae through a BLAST search that was classified into 24 families. The CYP51 family had the highest number of enriched genes (100), followed by CYP715 (42), and CYP53 (34).

Pathogens can primarily use CAZymes to destroy the polysaccharide component of the host cell wall during the beginning of infection [49]. As Saccharomycopsis phalluae, this study confirmed that it was the pathogens of yellow rot disease on P. rubrovolvatus. We searched the CAZy database for CAZymes, carbohydrate-binding modules, and auxiliary proteins in the 2020060402-1 genome. A total of 220 CAZyme-encoding gene models were assigned across the six categories of CAZymes, including Glycosyl transferases (GTs; 92), Glycoside hydrolases (GHs; 85), Auxiliary activities (AAs; 21), Carbohydrate esterases (CEs; 15), Carbohydrate-binding module (CBMs; 4) and Polysaccharide lyases (PLs; 3) (Table 4). Based on the study of Xu et al. [50], most genes encoded GH and GT enzymes, might be used to degrade the host cell barrier during the fungi-fungi infection process, across three mushroom pathogens (Cladobotryum dendroides, C. protrusum, and Mycogone perniciosa). Significantly, there were 177 gene models predicted in S. phalluae genome, accounting for $80.45 \%$ of the total.

Table 4. Carbohydrate-active enzyme annotation results in S. phalluae.

\begin{tabular}{cc}
\hline Classification & Number \\
\hline Carbohydrate-binding module (CBMs) & 4 \\
Carbohydrate esterase (CEs) & 15 \\
Glycoside hydrolase (GHs) & 85 \\
Glycosyl transferase (GTs) & 92 \\
Polysaccharide lyase (PLs) & 3 \\
Auxiliary activities (AAs) & 21 \\
\hline
\end{tabular}

\subsection{Phylogenomics Analysis of S. phalluae}

There were 1584 orthogroups with all species present. We next analyzed 794 single copy orthogroups that were conserved across all of the fungi analyzed (Figure 10). The phylogenetic analysis indicated that our new collection, S. phalluae, clustered with S. fodiens, whereas Saccharomycopsis (Saccharomycopsidaceae) is distantly related to Ascoidea (Alloascoideaceae) (Figure 10). The analysis results coincide with those based on LSU rRNA sequences analysis (Figure 2). Unfortunately, the genome sequences of several species in Saccharomycopsis have not been obtained. 


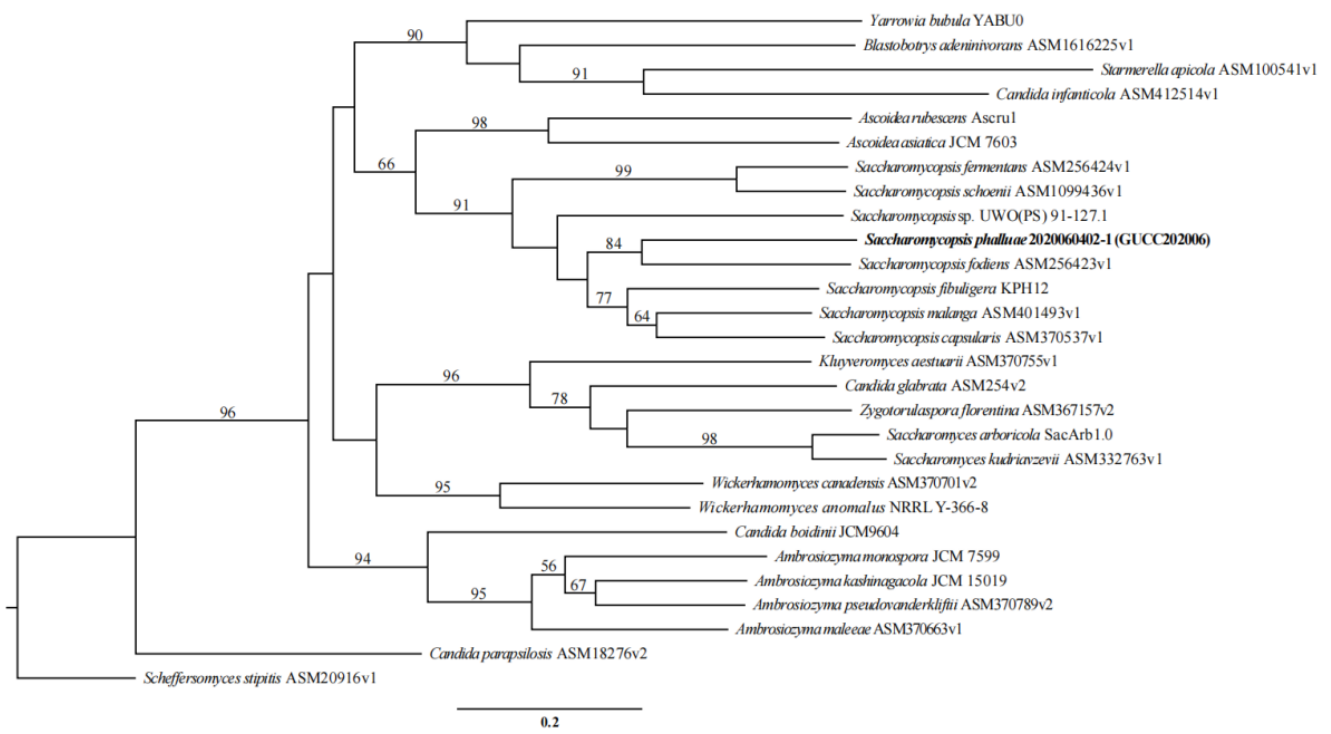

Figure 10. Phylogenetic tree of S. phalluae and 27 other fungal species. Maximum likelihood (ML) values $>50 \%$ were placed close to topological nodes, with 794 single copy orthologs. The tree was rooted to Scheffersomyces stipitis CBS 6054, Saccharomycopsis phalluae sp. nov. was in bold.

\section{Discussion}

Yellow rot disease is a disastrous disease of $P$. rubrovolvatus. The diseased tissues rapidly become colonized by massive amounts of contaminating microorganisms so identifying the causal agent has been challenging [5-8]. To determine the cause of the disease, diseased samples at various stages were collected from the cultivation areas. All isolates were purified and inoculated on healthy fruiting bodies by non-invasive inoculation. The result showed that only the yeast-like fungi were pathogenic. Typical yellow rot disease symptoms were observed 3-7 days after inoculation, whereas the controls remained healthy. Thus, the yeast-like fungi were identified as the cause of yellow rot disease. A phylogenetic tree, inferred by the ML, MP, and BI approach based on the LSU gene sequences, confirmed the two isolates as a new taxon. On the basis of the phylogenetic analysis and morphological characteristics, the causal agent was introduced herein as Saccharomycopsis phalluae sp. nov. It is characterized by having ellipsoidal to elongate cells, the colony turning reddish-brown in the center after 5 days on YPG agar and with regular margins on cultures instead of ovoid to short cylindroid cells, without turning reddish-brown and with irregular margins to the closed species S. oxydans, respectively. In the phylogenetic tree, there are several unidentified Candida spp. clustered with Saccharomycopsis spp., indicating their misidentification. However, their taxonomic placements need to be further studied.

It is the first pathogen in Saccharomycopsidaceae that were reported on mushroom in China. However, with the rapid development of the planting industry of P. rubrovolvatus, the occurrence of yellow rot disease is becoming more and more serious. The severe disease (yellow rot disease) on P. rubrovolvatus occurs extensively in China, and causes major economic losses and hinders in the industry. The occurrence of yellow rot disease on various varieties of $P$. rubrovolvatus in different areas needs further investigation, so as to provide a scientific theoretical basis for clarifying the occurrence and epidemic conditions related to the disease. In the future, disease resistance breeding may be useful to control the disease.

However, in plants and other mushroom cultivation, there is no disease caused by Saccharomycopsis. In order to comprehensively analyze the relationship between S. phalluae and related species and genera, 27 fungal species were used in the phylogenetic analysis. The result showed that $S$. phalluae formed a distinct branch to $S$. fodiens in the clade of Saccharomycopsis genus. This result is consistent with the analysis results based on the LSU 
sequence. To some extent, this also supports the statement that the LSU gene is used as the classification basis of this group.

A total of 5966 genes were predicted from S. phalluae in different databases with genome size of $14.148 \mathrm{Mb}$, While the genome size of other species in the genus ranges from $12.192 \mathrm{Mb}$ to $19.567 \mathrm{Mb}$, and the number of annotated genes ranges from 5359 to 6736, respectively (Table S1). This provides basic data for the analysis of pathogenic genes, biosynthesis and other functional genes of this species. There were 4015 proteins in S. phalluae assigned to NCBI KOG categories. The representation of genes related to protein and energy metabolism could reflect the capacity of $S$. phalluae to absorb and transform nutrients from a variety of substrates. It is understood that CAZymes play a relevant role in virulence. Most chitinase- and cellulose-degrading enzymes are categorized within the GH class and the abundance of GH18 was consistent with the efficient degradation of chitinase, cellulose, and hemicellulose [51]. There were 85 GHs and 92 GTs predicted in the genome of $S$. phalluae accounting for $80.45 \%$ of the total CAZymes, which may be the pathogenicity related genes that might be used to degrade the host cell barrier (chitinase, cellulose, and hemicellulose, or other organizational structure) during the fungi-fungi infection process [49-51]. Of the GH families, GH18 was encoded by the most genes (12) in S. phalluae, which suggested that these enzymes might play a role in the genome of our pathogen. There were 21 AA (Auxiliary activities) genes in the S. phalluae genome, among them, 9 AA3 (glucose-methanol-choline oxidoreductase) was the most abundant.

Pathogenic fungi can cause huge damage to the host. The effectors are important virulence determinants of pathogenic fungi and play important role in successful pathogenesis, predominantly through targeting and regulating the phytohormone signaling of hosts by changing or operating them [52]. There are 210 effectors found in S. phalluae, which were also found in the pathogens, such as Fusarium graminearum, Magnaporthe oryzae, Ustilago maydis, Botrytis cinerea, Verticillium dahliae, Aspergillus fumigatus, Cochliobolus carbonum, Erwinia amylovora, Septoria lycopersici, Colletotrichum lindemuthianum, Bipolaris sorokiniana and Paenibacillus larvae. Pathogens may optimize their own effector sets to adapt to hosts, as several effector proteins in mushroom pathogens (C. protrusum and $M$. perniciosa) $[53,54]$. In addition, Yin et al. reported that pathogens could secrete many proteins that can support the colonization of the host surface during infection [55]. From the results of analysis on S. phalluae, most of the 1779 candidate pathogenicity-related proteins are with PHI-base. These findings could be instrumental for the understanding of fungi-fungi interactions, and for exploring efficient management strategies to control the disease.

Supplementary Materials: The following are available online at https:/ / www.mdpi.com/article/ 10.3390 /jof7090707/s1, Figure S1. Pathogenicity tests of the other 26 strains isolated from diseased fruiting bodies of $P$. rubrovolvatus. Left are the fruiting bodies with no disease symptom, sprayed with $0.5 \mathrm{~mL}$ spore suspension $\left(1 \times 10^{6} \mathrm{Cell} \mathrm{mL}^{-1}\right), 7$ days after inoculation; the right are the colony morphology of the strains. Table S1. Summary of fungi analyzed in this study and origin of their genomes (note: "-", not clear). Table S2. Genes predicted to be involved in miRNA in S. phalluae. Table S3. S. phalluae gene annotations.

Author Contributions: Conceptualization, F.T. and Y.L.; Data curation, X.Y. and K.P.; Funding acquisition, F.T.; Investigation, X.Y. and K.P.; Methodology, Z.Z. and X.Z.; Resources, Y.L.; Software, X.Z.; Supervision, C.L. and F.T.; Validation, Z.Z. and Y.L.; Visualization, F.T.; Writing-original draft, X.Y.; Writing-review and editing, C.L. and F.T.; All authors have read and agreed to the published version of the manuscript.

Funding: This research was funded by the Science and Technology Projects of Guizhou Province Cultivation, grant number Support of QKH [2021] General 199; Cultivation Project of Guizhou University, grant number [2019]46; Natural Science Research Projects of Guizhou Education Department, grant number [2021]054; Natural Science Special (Special Post) Scientific Research Fund Project of Guizhou University, grant number 2019(13); Major Special Characters of QianKeHe, grant number QKH [2019]3005; and Science and Technology Innovation Team of Guizhou Province, grant number QKHPTRC [2020]5001. 
Institutional Review Board Statement: Not applicable.

Informed Consent Statement: Not applicable.

Data Availability Statement: The genome sequence data and assembly reported in this paper are associated with NCBI BioProject: PRJNA721835, BioSample: SAMN18740300 and Accession Number: CP073212-CP073219 in GenBank.

Acknowledgments: The authors would like to thank Guizhou Jinchan Dashan Biotechnology Co., Ltd. for providing collection and research materials.

Conflicts of Interest: The authors declare that the research was conducted in the absence of any commercial or financial relationships that could be construed as a potential conflict of interest.

\section{References}

1. Lu, Y.Y.; Gui, Y.; Lu, G.G.; Yuan, W.S.; Zhu, G.S. Genetic diversity of 18 Dictyophora rubrovolvata germplasm resources from Guizhou. Guizhou Agric. Sci. 2014, 42, 17-20.

2. $\quad$ Li, Y.; Li, T.H.; Yang, Z.L.; Tu, L.G.E.; Dai, Y.C. Atlas of Chinese Macrofungal Resources; Central Plains Farmers Press: Zhengzhou, China, 2015; p. 1166.

3. Zhuang, Y.L.; Sun, L.P. Nutritional characteristics of proteins from the volva and pileus in cultivated mushroom Dictyophora rubrovolvata. Int. J. Food Sci. Nutr. 2011, 62, 392-396. [CrossRef]

4. Sun, L.P.; Bao, C.J.; Chang, W.D.; Zhuang, Y.L. Preparation, characterisation, antioxidant and antiglycation activities of the novel polysaccharides from the pileus of Dictyophora rubrovolvata. Food Sci. Technol.-Braz. 2017, 52, 161-170.

5. Lu, Y.Y.; Gui, Y.; Chen, Y.Y.; Zeng, G.S.; Zhu, G.S. Preliminary study on the Dictyophora rubrovolvata rot disease. Edible Fungi China 2018, 37, 73-76, 78.

6. Li, J.Y.; Wu, S.R.; Liu, C.L.; Shang, L.E.; Luo, X.K.; Liu, S.X. Study on fungi infecting in the Dictyophora rubrovolvata rot disease. Edible Fungi China 2021, 40, 109-112.

7. Chen, X.Y.L.; Zhou, X.H.; Zhao, J.; Tang, X.L.; Pasquali, M.; Migheli, Q.; Berg, G.; Cernava, T. Occurrence of green mold disease on Dictyophora rubrovolvata caused by Trichoderma koningiopsis. J. Plant Pathol. 2021, 103, 981-984. [CrossRef]

8. Pan, G.C.; Long, H.W.; Wu, D.; Chen, X.; Dai, L.H.; Sun, Y.; Zhou, F.L. Occurrence of bark-rot disease on Dictyophora rubrovolvata and its prevention in Guizhou Province. Edible Fungi China 2015, 34, 72-75.

9. Schionning, H. Nouveau genre de la famille des Saccharomycetes. Compt. Rend. Trav. Lab Carlsberg 1903, 6, 101-125.

10. Suh, S.O.; Blackwell, M.; Kurtzman, C.P.; Lachance, M.A. Phylogenetics of Saccharomycetales, the ascomycete yeasts. Mycologia 2006, 98, 1006-1017. [CrossRef]

11. Jacques, N.; Louis-Mondesir, C.; Coton, M.; Coton, E.; Casaregola, S. Two novel Saccharomycopsis species isolated from black olive brines and a tropical plant. Description of Saccharomycopsis olivae f. a., sp. nov. and Saccharomycopsis guyanensis f. a., sp. nov. Reassignment of Candida amapae to Saccharomycopsis amapae f. a., comb. nov., Candida lassenensis to Saccharomycopsis lassenensis $\mathrm{f}$. a., comb. nov. and Arthroascus babjevae to Saccharomycopsis babjevae f. a., comb. nov. Int. J. Syst. Evol. Microbiol. 2014, 64, $2169-2175$.

12. Jin, J.H.; Hanh, N.T.T.; Sanjida, H.; Park, S.H.; Hyewon, O.; Lim, S.; Mok, I.-K.; Li, Y.; Pal, K.; Kim, D. Characteristics of sourdough bread fermented with Pediococcus pentosaceus and Saccharomyces cerevisiae and its bio-preservative effect against Aspergillus flavus. Food Chem. 2021, 345, 128787. [CrossRef]

13. Iacumin, L.; Manzano, M.; Andyanto, D.; Comi, G. Biocontrol of ochratoxigenic moulds (Aspergillus ochraceus and Penicillium nordicum) by Debaryomyces hansenii and Saccharomycopsis fibuligera during speck production. Food Microbiol. 2017, 62, 188-195. [CrossRef] [PubMed]

14. Tian, F.H.; Li, C.T.; Li, Y. First report of Penicillium brevicompactum causing blue mold disease of Grifola frondosa in China. Plant Dis. 2017, 101, 1549. [CrossRef]

15. Kurtzman, C.P. Two new members of the Saccharomycopsis clade: Saccharomycopsis microspora comb. nov. and Candida lassenensis, sp. nov. Mycotaxon 1999, 71, 241-250.

16. Kurtzman, C.P.; Fell, J.W.; Boekhout, T. The Yeasts, a Taxonomic Study, 5th ed.; Elsevier Science: Amsterdam, The Netherlands, 2011; pp. 87-110.

17. Hajihosseinali, M.; Nasr, S.; Amoozegar, M.A.; Yurkov, A. Saccharomycopsis oxydans sp. nov., a new non-fermentative member in the genus Saccharomycopsis isolated from a traditional dairy product of Iran. Int. J. Syst. Evol. Microbiol. 2020, 70, 1059-1063. [CrossRef]

18. Barnett, J.A.; Payne, R.W.; Yarrow, D. Yeasts: Characteristics and Identification, 3rd ed.; Cambridge University Press: Cambridge, UK, 2000; pp. 8-16.

19. White, T.J.; Bruns, T.D.; Lee, S.B.; Taylor, J.W. Amplification and direct sequencing of fungal ribosomal RNA genes for phylogenetics. In PCR Protocols: A Guide to Methods and Applications; Innis, M.A., Gelfand, D.H., Sninsky, J.J., White, T.J., Eds.; Academic Press Inc.: New York, NY, USA, 1990; pp. 315-322.

20. O'Donnell, K. Fusarium and Its Near Relatives. The Fungal Holomorph: Mitotic, Meiotic and Pleomorphic Speciation in Fungal Systematic; Reynolds, D.R., Taylor, J.W., Eds.; CAB International: Wallingford, UK, 1993; pp. 225-233. 
21. Kurtzman, C.P.; Robnett, C.J. Identification of clinically important ascomycetous yeasts based on nucleotide divergence in $5^{\prime}$ end of the large subunit (26S) ribosomal DNA gene. J. Clin. Microbiol. 1997, 35, 1216-1223. [CrossRef]

22. Kurtzman, C.P.; Robnett, C.J. Identification and phylogeny of ascomycetous yeasts from analysis of nuclear large subunit (26S) ribosomal DNA partial sequences. Antonie Leeuwenhoek 1998, 73, 331-371. [CrossRef]

23. Lachance, M.A.; Rosa, C.A.; Carvajal, E.J.; Freitas, L.F.D.; Bowles, J.M. Saccharomycopsis fodiens sp., nov., a rare predacious yeast from three distant localities. Int. J. Syst. Evol. Microbiol. 2012, 62, 2793-2798. [CrossRef]

24. Hall, T.A. BioEdit: A user-friendly biological sequence alignment editor and analysis program for Windows 95/98/NT. Nucl. Acids Symp. Ser. 1999, 41, 95-98.

25. Miller, M.A.; Pfeiffer, W.; Schwartz, T. Creating the CIPRES Science Gateway for inference of large phylogenetic trees. In Gateway Computing Environments Workshop (GCE); IEEE Computer Society: Washington, DC, USA, 2010.

26. Berlin, K.; Koren, S.; Chin, C.S.; Drake, J.; Landolin, J.M.; Phillippy, A.M. Assembling large genomes with single-molecule sequencing and locality sensitive hashing. Nat. Biotechnol. 2015, 33, 623-630. [CrossRef] [PubMed]

27. Koren, S.; Phillippy, A.M. One chromosome, one contig: Complete microbial genomes from long-read sequencing and assembly. Curr. Opin. Microbiol. 2015, 23, 110-120. [CrossRef]

28. Walker, B.J.; Abeel, T.; Shea, T.; Priest, M.; Abouelliel, A.; Sakthikumar, S.; Cuomo, C.A.; Zeng, Q.; Wortman, J.; Young, S.K.; et al. Pilon: An Integrated Tool for Comprehensive Microbial Variant Detection and Genome Assembly Improvement. PLoS ONE 2014, 9, e112963. [CrossRef] [PubMed]

29. Zhang, C.H.; Deng, W.Q.; Yan, W.J.; Li, T.H. Whole genome sequence of an edible and potential medicinal fungus, Cordyceps guangdongensis. G3 Genes Genom. Genet. 2018, 8, 1863-1870. [CrossRef] [PubMed]

30. Stanke, M.; Keller, O.; Gunduz, I.; Hayes, A.; Waack, S.; Morgenstern, B. AUGUSTUS: Ab initio prediction of alternative transcripts. Nucleic Acids Res. 2006, 34, W435-W439. [CrossRef] [PubMed]

31. Saha, S.; Bridges, S.; Magbanua, Z.V.; Peterson, D.G. Empirical comparison of ab initio repeat finding programs. Nucleic Acids Res. 2008, 36, 2284-2294. [CrossRef] [PubMed]

32. Benson, G. Tandem repeats finder: A program to analyze DNA sequences. Nucleic Acids Res. 1999, 27, 573-580. [CrossRef]

33. Li, W.Z.; Jaroszewski, L.; Godzik, A. Tolerating some redundancy significantly speeds up clustering of large protein databases. Bioinformatics 2002, 18, 77-82. [CrossRef]

34. Ashburner, M.; Ball, C.A.; Blake, J.A.; Botstein, D.; Butler, H.; Cherry, J.M.; Davis, A.P.; Dolinski, K.; Dwight, S.S.; Eppig, J.T.; et al. Gene Ontology: Tool for the unification of biology. Nat. Genet. 2000, 25, 25-29. [CrossRef]

35. Tatusov, R.L.; Fedorova, N.D.; Jackson, J.D.; Jacobs, A.R.; Kiryutin, B.; Koonin, E.V.; Krylov, D.M.; Mazumder, R.; Mekhedov, S.L.; Nikolskaya, A.N.; et al. The COG database: An updated version includes eukaryotes. BMC Bioinform. 2003, 4, 41. [CrossRef] [PubMed]

36. Finn, R.D.; Mistry, J.; Schuster-Böckler, B.; Griffiths-Jones, S.; Hollich, V.; Lassmann, T.; Moxon, S.; Marshall, M.; Khanna, A.; Durbin, R.; et al. Pfam: Clans, web tools and services. Nucleic Acids Res. 2006, 34, D247-D251. [CrossRef]

37. Kanehisa, M.; Goto, S.; Kawashima, S.; Okuno, Y.; Hattori, M. The KEGG resource for deciphering the genome. Nucleic Acids Res. 2004, 32, D277-D280. [CrossRef]

38. Kanehisa, M.; Goto, S.; Hattori, M.; Aoki-Kinoshita, K.F.; Itoh, M.; Kawashima, S.; Katayama, T.; Araki, M.; Hirakawa, M. From genomics to chemical genomics: New developments in KEGG. Nucleic Acids Res. 2006, 34, D354-D357. [CrossRef] [PubMed]

39. Bairoch, A.; Apweiler, R. The SWISS-PROT protein sequence data bank and its new supplement TrEMBL. Nucleic Acids Res. 1996, 25, 31-36. [CrossRef] [PubMed]

40. Saier, M.H., Jr.; Reddy, V.S.; Tamang, D.G.; Västermark, Å. The transporter classification database. Nucleic Acids Res. 2014, 42, D251-D258. [CrossRef] [PubMed]

41. Urban, M.; Pant, R.; Raghunath, A.; Irvine, A.G.; Pedro, H.; Hammond-Kosack, K.E. The Pathogen-Host Interactions database (PHI-base): Additions and future developments. Nucleic Acids Res. 2015, 43, D645-D655. [CrossRef]

42. Coleine, C.; Masonjones, S.; Sterflinger, K.; Onofri, S.; Selbmann, L.; Stajich, J.E. Peculiar genomic traits in the stress-adapted cryptoendolithic Antarctic fungus Friedmanniomyces endolithicus. Fungal Biol. UK 2020, 124, 458-467. [CrossRef]

43. Nelson, D.R. The cytochrome P450 homepage. Hum. Genom. 2009, 4, 59-65. [CrossRef]

44. Li, L.; Stoeckert, C.J.; Roos, D.S. OrthoMCL: Identification of ortholog groups for eukaryotic genomes. Genome Res. 2003, 13, 2178-2189. [CrossRef] [PubMed]

45. Chen, L.; Gong, Y.; Cai, Y.; Liu, W.; Zhou, Y.; Xiao, Y.; Xu, Z.; Liu, Y.; Lei, X.; Wang, G.; et al. Genome Sequence of the Edible Cultivated Mushroom Lentinula edodes (Shiitake) Reveals Insights into Lignocellulose Degradation. PLoS ONE 2016, 11, e0160336. [CrossRef] [PubMed]

46. Sievers, F.; Higgins, D.G. Clustal omega for making accurate alignments of many protein sequences. Protein Sci. $2017,27,135-145$. [CrossRef]

47. Stamatakis, A. RAxML version 8: A tool for phylogenetic analysis and post-analysis of large phylogenies. Bioinformatics 2014, 30, 1312-1313. [CrossRef] [PubMed]

48. Von Arx, J.A.; Rodríguez de Miranda, L.; Smith, M.T.; Yarrow, D. The genera of yeasts and the yeast-like fungi. Stud. Mycol. 1977, $14,9-10$. 
49. Bashyal, B.M.; Rawat, K.; Sharma, S.; Kulshreshtha, D.; Krishnan, S.G.; Singh, A.K.; Dubey, H.; Solanke, A.U.; Sharma, T.R.; Aggarwal, R. Whole Genome Sequencing of Fusarium fujikuroi Provides Insight into the Role of Secretory Proteins and Cell Wall Degrading Enzymes in Causing Bakanae Disease of Rice. Front. Plant Sci. 2017, 8, 2013. [CrossRef]

50. Xu, R.; Liu, X.; Peng, B.; Liu, P.; Li, Z.; Dai, Y.; Xiao, S. Genomic Features of Cladobotryum dendroides, Which Causes Cobweb Disease in Edible Mushrooms, and Identification of Genes Related to Pathogenicity and Mycoparasitism. Pathogens 2020, 9, 232. [CrossRef] [PubMed]

51. Huang, Q.-S.; Xie, X.-L.; Liang, G.; Gong, F.; Wang, Y.; Wei, X.-Q.; Wang, Q.; Ji, Z.-L.; Chen, Q.-X. The GH18 family of chitinases: Their domain architectures, functions and evolutions. Glycobiology 2011, 22, 23-34. [CrossRef]

52. Pradhan, A.; Ghosh, S.; Sahoo, D.; Jha, G. Fungal effectors, the double edge sword of phytopathogens. Curr. Genet. 2021, 67, 27-40. [CrossRef] [PubMed]

53. Li, D.; Sossah, F.L.; Sun, L.; Fu, Y.P.; Li, Y. Genome analysis of Hypomyces perniciosus, the causal agent of wet bubble disease of button mushroom (Agaricus bisporus). Genes 2019, 10, 417. [CrossRef]

54. Sossah, F.L.; Liu, Z.H.; Yang, C.T.; Okorley, B.A.; Sun, L.; Fu, Y.P.; Li, Y. Genome sequencing of Cladobotryum protrusum provides insights into the evolution and pathogenic mechanisms of the cobweb disease pathogen on cultivated mushroom. Genes 2019, 10, 124. [CrossRef]

55. Yin, Z.Y.; Liu, H.Q.; Li, Z.P.; Ke, X.W.; Dou, D.L.; Gao, X.N.; Song, N.; Dai, Q.; Wu, Y.; Xu, J.; et al. Genome sequence of Valsa canker pathogens uncovers a potential adaptation of colonization of woody bark. New Phytol. 2015, 208, 1202-1216. [CrossRef] 